\section{EDITORIAL BOARD}

Editor and Chair

Peggy Johnson

\section{Members}

Steven B. Carrico, University of

Florida

Elise Calvi, Indiana Historical

Society

Allyson Carlyle, University of

Washington

Leslie Czechowski, University of

Pittsburgh Health Sciences Library

Lewis Brian Day, Harvard

University

October Ivins, Ivins eContent

Solutions

Edgar Jones, National University

Steven A. Knowlton, University of

Memphis

Birdie MacLennan, University of

Vermont

Rebecca L. Mugridge, Pennsylvania State University

Randy Roeder, University of Iowa

Carlen Ruschoff, University of

Maryland

Sarah Simpson, Tulsa City-County

Library System

Anne M. Sleeman, Community

College of Baltimore County

Catonsville

Lori Terrill, University of Wyoming

Elaine L. Westbrooks, University of Nebraska-Lincoln

Lynn N. Wiley, University of Illinois

at Urbana-Champaign

\section{Ex-Officio Members}

Charles Wilt, Executive Director, ALCTS

Alice Platt, Southern New Hampshire University, Editor, ALCTS Newsletter Online

Norm Medeiros, Haverford College Book Review Editor, LRTS

\section{Editorial}

\section{Peggy Johnson}

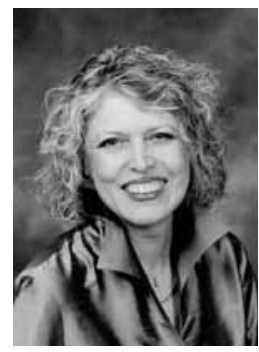

Tam writing this editorial in late December in very unusual 1 weather for Minnesota. We have no snow on the ground and yesterday the temperature was the same in Minneapolis as it was in Atlanta. Many things are veering from the expected. Does that mean we should not plan for the future because the future is so unpredictable? I still have my winter emergency supplies loaded in the car even though this winter has been mild and is likely to continue milder than last year. I consider this a form of contingency planning. Contingency planning is directed toward preparing for one possible and usually undesirable future. Libraries prepare disaster contingency plans. Such a plan begins by identifying the possible disaster, such as a flood, and consequences for facilities, services, and collections, and develops appropriate steps to respond to those circumstances.

What other types of planning do libraries use? Master planning is top-down planning that begins in an administrative office. Unit plans are prepared consistent with the master plan. This approach, although it means that initiative at the unit level is constrained and the master plan may not account for the reality of day-to-day work, is fairly simple because not much is open to debate. Strategic planning has an external focus and requires continually monitoring changes in the environment to devise an appropriate response. It usually begins with a vision of the organization's future that serves as a guide to crafting goals, objectives, and strategies that form the plan. Strategic planning is broadly participative and remains an open-ended, continuous process revised at regular intervals. Scenario planning considers alternative futures and formulates strategies in each of those futures. A common example has been planning for various budget allocationswhat would the library due with a 3 percent increase, a flat budget, a 3 percent decrease, a 5 percent decrease? Opportunistic planning, sometimes called entrepreneurial planning, is a laissez-faire approach and implies acting immediately when and while an opportunity arises. This approach can make librarians frantic because they do not know what is coming next and when or how they will have to do something completely different.

Drucker wrote that formal planning is improving the "futurity" of decisions. ${ }^{1}$ Some of the approaches to planning describes above do so, others do not. I have spent much of my professional career involved in planning-for a new automated system, a system upgrade, a revised cataloging code, a retrospective conversion project, collection moves, new facilities, a withdrawal project, and more. I have found that the more detailed the plans, the better the projects go. If, for example, a collection must be moved by a certain date, one develops a project calendar working backward from that date. Gantt charts are a useful tool for mapping the sequence of steps and the dependencies, clarifying tasks and responsibilities, and tracking the completion of each assignment. I love a plan because it can look so orderly. The caveat is that projects never go as planned. Eisenhower is credited with saying "In preparing for battle, I have always found that plans are useless but planning is indispensable."2 Most projects are not as orderly as one would like, but starting with a plan and recognizing that it will 
have to be revised as the project advances will improve the futurity of any initiative.

One of my favorite gifts this past Christmas was a Lego kit to build the Frank Lloyd Wright-designed house, Fallingwater. It contained 801 pieces and took me nearly eight hours to complete. I loved it! I have been pondering why the project was so much fun. I think one reason I enjoyed it is because Lego kits are so orderly-the instructions are detailed and clear, one completes each step (which may have several steps within it) before moving on to the next, and, when one does the steps in order, the result is an impressive project one can admire. I wish all library projects came with printed, spiral-bound instructions, and were as straightforward and as satisfying as a Lego kit.

\section{References}

1. Peter Drucker, Management: Tasks, Responsibilities, Practices (New York: Harper \& Row, 1974): 125.

2. Notable Quotes, Dwight D. Eisenhower Quotes, www .notable-quotes.com/e/eisenhower_dwight_d.html (accessed Dec. 27, 2011).

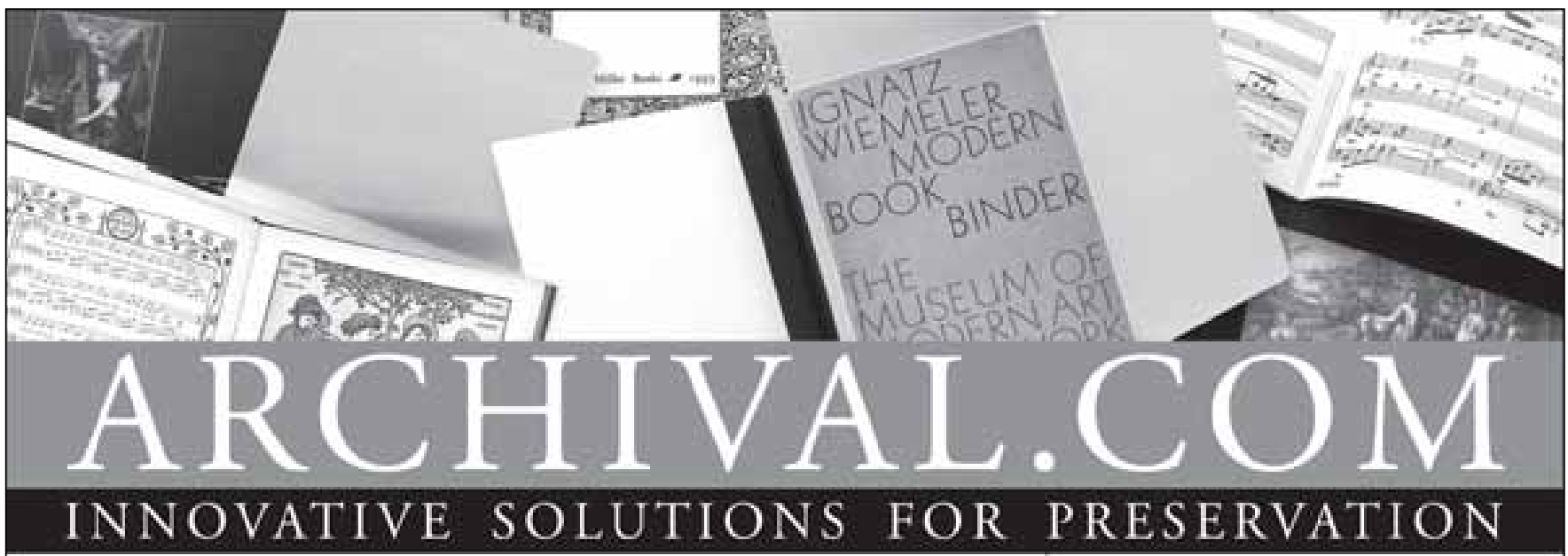

Call for a complete catalog

Pamplitet Binden

Musis Binden

Andival Folders

Manuscript Folders

Hinge Board Cousn

Acadeny Folders

Neuspaper/Map Folders

Bound Four Flap

Endosures

Archival Binders
Polypmopyleue Sbeet o Phota Pnotectans Anbival Boutsls

Adheitives

Booklecper

Century Baves

Conseristion Cloths

Non-Glare Polypropylene Book Covers

CoLibri Book Cover System

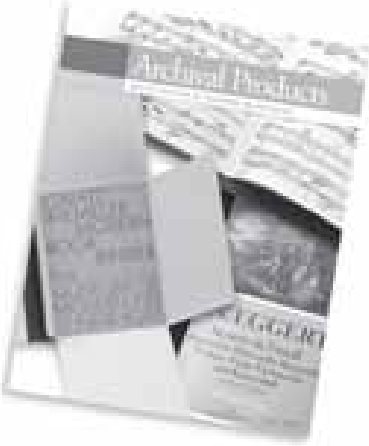

ARCHIVAL PRODUCTS

P.O. Box 1413

Des Moines, lowa 50306-1413

Phone: 800.526.5640

Fax: 888.220 .2397

E-mail: custserv@archival.com

Web: archival.com 